\title{
Learning Strategy of Production of Tempe Through Various Size of Soybean Particles for Students with Hearing Impairments
}

\author{
Yulvia Sani ${ }^{1,2}$, Asep Bayu Dani Nandiyanto",*, Ossy Firstanti Wardany, Achmad Hufad ${ }^{1, * *}$, \\ Endang Rochyadi ${ }^{1}$ \\ ${ }^{1}$ Universitas Pendidikan Indonesia, Jl. Dr. Setiabudhi No. 229 Bandung, Indonesia \\ ${ }^{2}$ Program Studi Pendidikan Luar Biasa, Universitas Muhammadiyah Lampung, Jl. Z.A Pagar Alam No.14 Bandar Lampung \\ Indonesia \\ 1yulviasani10@upi.edu,nandiyanto@upi.edu, achmadhufad@upi.edu, endangrochyadi@upi.edu \\ 2ossyfirstan@gmail.com
}

\begin{abstract}
The aim of this study was to find a strategy to teach how to make tempe in biotechnology materials through various particle sizes of soybeans to students with hearing impairments at the high school level. This research method used a single subject approach with pre-test and post-test designs with 10 students with hearing impairments, aged 1921 years, in Bandar Lampung, Indonesia. Learning strategies in the form of experimental demonstration, using the original media, and total communication (sign language, oral, speech reading, and writing). The results of the experiment showed that the more yeast used on the soybean particles, the more the fungus binds the soybeans, thus making the durability better. Teaching results show students with hearing impairments can understand all material about biotechnology in making tempe with various particle sizes. The experimental demonstration strategy provides concrete explanations about making tempe from various particle sizes of soybeans. Students' learning needs are well accommodated to provide a meaningful learning experience for students with hearing impairment.
\end{abstract}

Keywords: Biotechnology, Experimental Demonstration, Learning Strategy, Soybeans Particle, Students with hearing impairments, Tempe.

\section{Corresponding Author}

*Universitas Pendidikan Indonesia, Jl. Dr. Setiabudhi

No. 229 Bandung, Indonesia

*nandiyanto@upi.edu

** Universitas Pendidikan Indonesia, Jl. Dr.

Setiabudhi No. 229 Bandung, Indonesia

**achmadhufad@upi.edu

\section{Introduction}

Tempe is one of the Indonesia's traditional food. Tempe is produced through simple fermentation techniques by Rhizopus sp. (Kharisma, Mahadi and Darmawati, 2015). Tempe is a major fermented soya bean food and is known for its attractive flavor, texture, and superior digestibility (Nout and Kiers, 2005). It takes time to ferment in order to make good quality tempe. Many studies discuss the fermentation time of tempe to produce high quality. Tempe in Indonesia generally fermented at room temperature, which is around $25^{\circ} \mathrm{C}$ for $44-52 \mathrm{~h}$ (Mukhoyaroh, 2015). In over fermented (at 50-90 h), there will be an increase in the number of bacteria and the amount of free fatty acids, making the growth of the fungus decrease (at certain water levels, the fungus stops growing), which causes a change in taste due to further protein degradation to form ammonia (Hidayat, 2009). Tempe fermented with $R$. oligosporus for 10 days exhibited the highest antioxidant activities (Chang, Hsu,Chen, Huang and Chung, 2009). Tempe is a product of conventional biotechnology which is a subject matter for Biology in high school, more specifically about food fermentation (Setiawati, Darmawati, and Imam, 2016).

There have been a lot of research on biotechnology, especially on food fermentation for non-disabled students in high school (Mulyono, 2012; Rahayu, 2020; Tanjung, 2019; Sulfanita, 2018), but it is difficult to find studies on the same areas for students with hearing impairments. Hearing impairment is one of the most common disabilities in the human population and presents a great risk in everyday life due to problems with speech recognition, communication, and language acquisition (Ohlenforst, Zekveld, Jansma, Wang, Naylor, Lorens, Lunner, and Kramer, 2017). Teaching students with hearing impairments require a particular strategy. The appropriate strategies will help students understand the concept of learning materials (Nehru 
and Syarkowi, 2017). Biotechnology is a complex theme that is directly or indirectly exist in our lives, from food to medicine. Despite that, understanding of biotechnology is still difficult for most of society due to this complexity (Mariani, Delou, Souza, Valentim, Passos, Rosa, Farias, Marrocos Moraes and Castro, 2014). This is a challenge for teachers to bring up a good understanding of students. This is not only lesson in school but also relates to its application in the real world. Teachers should pay attention and consider strategies to teach making tempe from various soybean particles to students with hearing impairments. However, the concepts of procedure and principles in making tempe is an abstract concept for students with hearing impairments.

Science for students with hearing impairments needs to be considered. Extensive material provides opportunities for them to develop vocabulary and thinking skills (Ntinda, Thwala, and Tfusi, 2019). Students with hearing impairment's language comprehension generally are overlooked or ignored but nonetheless, these are of central importance if educational interventions are to be effective (Marschark and Wauters, 2008). Therefore, teaching various types of knowledge is important, including learning to make tempe, which is the implementation of biotechnology that we often find in daily life.

Different from other studies, this research has authenticity, (1) this research has a novelty, (2) limited research on the manufacture of tempe of various particle sizes for students with hearing impairments (3) The demonstration experiment strategy provides increased understanding of students with hearing impairments. about the concept of biotechnology (making tempe), and increasing their vocabulary, (4) improve the skills of students with hearing impairments in making tempe from various particle sizes of soybeans.

The experimental demonstration strategy is a structured series of learning activities. This strategy provides a good learning experience for students with hearing impairments. Through independent trials and demonstration, students get used to arranging sentences well. Therefore, this learning strategy provides an opportunity for students with hearing impairments to understand the concepts, principles and procedures in the matter of making tempe. Then, the students carry out the principles of making tempe, paying attention to how to soak, clean, and ferment tempe. After the fermentation is complete, students with hearing impairments analyze the quality of tempe made from various particle sizes (durability, odor, and color). During the teaching process, especially in the experimental demonstration, the students are strictly asked to focus and clearly observe what phenomenon is happening (Nandiyanto, Raziqi, Dallyono, and Sumardi, 2020). Thus, students with hearing impairments understand abstract concepts thoroughly. Use of the demonstration experiment strategy allows students to discover the simple concept of biotechnology implementations in everyday life. This strategy also stimulates the thinking skills of students with hearing impairments to improve vocabulary, selfconfidence, and public speaking.

\section{Theoretical Framework}

\subsection{Processing method of tempe}

The method of preparation varies from one household to another, but the principle steps are basically similar. The soybeans are cleaned and then boiled in water for 30 minutes, before peeling them by hand. The peeled seeds are soaked overnight to allow full hydration and lactic acid fermentation. Then, soybean seeds cooked again for 60 minutes, dried using bamboo wicker baskets, and spread on a flat surface to be cooled to room temperature. In some cultures, soybeans are soaked in water until the skin can be easily removed by hand or foot and washed with water and then boiled until soft, usually for at least 30 minutes. This is to avoid cooking twice (Liu, 2015).

Figure 1 illustrates the process of making tempe. 3000 grams of soybeans used. The first soaking is for $5 \mathrm{~h}$, after that, it is boiled and then cleaned off the skin, then soaked again overnight, then boiled again, then dried. After drying, the soybeans are divided into three, namely 300 grams per container. The first particle size was fine powder by blending soybean beans, the second was coarse powder by chopping, the third was whole soybeans. Fine powder has a particle size of about 50-1100 um, coarse powder has a particle size of 100-1000 um (Aini, Hariyadi, Muchtadi and Andarwulan, 2010) and a whole bean size is around 1000-3600 um.

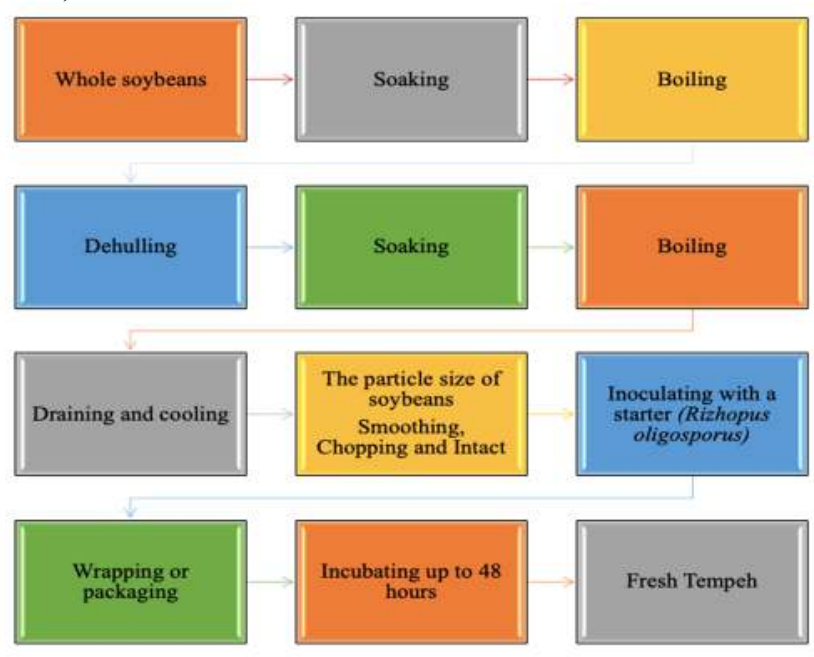

Fig. 1. Procedure for making tempe from various particle sizes of soybeans

\subsection{Processing principles of tempe}

There are many critical aspects of tempe fermentation, including temperature, $\mathrm{pH}$, and chemical composition of the soybean substrate. All of these are brought about by microbial growth and enzyme actions (Liu, 2015). The process of making tempe is influenced by several factors: temperature, humidity, and curing time. A good temperature for tempe to use for the fermentation process is at room temperature of $20-37^{\circ} \mathrm{C}$ with a slightly dark place, and a maximum temperature of $40^{\circ} \mathrm{C}$, because if the temperature is too high the growth of mold will not be perfect (Hassanein, Prabawati and Gunawan-Putri, 2015).

During the initial stage of fermentation, the mold spores germinate, and the temperature of the mass rises gradually. Subsequently, the mold grows rapidly, reaches a peak, and 
then gradually subsides. Concomitant with mold growth is the rise and fall of the temperature. At the peak, the temperature may be as high as $45^{\circ} \mathrm{C}$. By this time, the beans are already knitted into a compact mass by mold mycelia and the tempe is ready to be harvested. Beyond this stage, the mold sporulates, and $\mathrm{NH} 3$ is produced due to protein breakdown (Polanowska, Grygier, Kuligowski, Rudzińska and Nowak, 2020). As microorganisms grow, they produce various enzymes, which breakdown soybean components. This leads to compositional changes.

Compared with miso and soy sauce, these changes are much less vigorous due to the limited production of enzymes by the tempe mold. In comparison between tempe and unfermented dehulled soybeans, there are increased levels of free amino acids and free fatty acids, a slight decrease in oil content, and no significant changes in protein and ash contents. In addition, there are significant increases in the contents of several vitamins, including riboflavin, vitamin B6, nicotinic acid, pantothenic acid, biotin, and folacin. Some of these increases are several-fold, although thiamin was found to change little (Murata, Ikehata and Miyamoto 1967). Furthermore, in some tempe, vitamin B12 forms, which is widely attributed to the presence of certain contaminating bacteria, mainly Klebsiella (Utami, Wijaya and Lioe, 2016).

\section{Methods}

\subsection{Research subject}

This study used a single-subject approach with a pre-test and post-test design. The subjects in this study were 10 student with hearing impairments studying in special schools. The materials used in this study are soybeans produced by local farmers in Bandar Lampung, Indonesia, and tempe yeast (produced by PT. Aneka Fermentation Industri). The equipment used is tampah made of bamboo, container, pan, spatula made of wood, plastic gloves, and plastic zipper.

\subsection{Procedure of the experimental demonstration strategy}

Figure 2 illustrates the demonstration experimental strategy procedure for teaching the manufacture of tempe from various particle sizes of soybeans. In the first step, the teacher demonstrates the theories related to tempe, namely biotechnology, students understand what the teacher says. In the second step the teacher conducted a demonstration experiment about making tempe, the students tried to understand the stages of making tempe. The third step students conduct demonstration experiments about making tempe independently, the teacher facilitates, provides directions, and evaluates. The media used is the original media, the communication used is total communication (gesture, oral, reading speech, and writing). The teacher must pay attention to the direction of the face when communicating with the deaf, the direction of the teacher's face must be right with the vision of the student with hearing impairments to make it easier for them to understand what is being said.

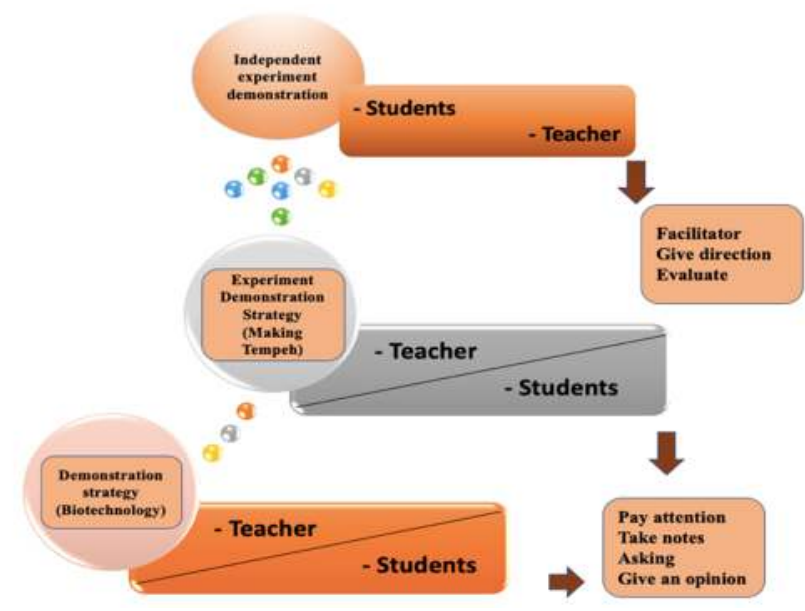

Fig. 2. Procedure of the experimental demonstration strategy

\section{Results and Discussions}

\subsection{Demographic data of student with hearing impairment}

Figure 3 shows the demographic data of students in integrated subjects on the theme of making tempe from various particle sizes of soybeans. Integrated subjects are science, math, vocational programs, and the Indonesian language. Students' abilities in these four subjects are very important to know, so that the strategy given is right.

Learning outcomes data from 10 students with hearing impairments have different ranges. In the vocational subject program, the scores obtained by each student have almost the same. The vocational program is a skills program, which is an educational program that has the aim of being able to acquire the skills or skills needed by students as a provision for life while plunging into the world of work or the world of society (Supriyanto, 2020). Vocational programs are usually in workshops. students and teachers interact and do a job freely in the workshop. Almost all students enjoy learning by doing, doing trials, success and failure have become commonplace for students in vocational programs. Student motivation is greater than learning only in class, listening, and then going home (Farooq, 2011). As with students with hearing impairments, learning by doing is a good way to understand what is being learned.

Indonesian subjects have almost the same score ranges among students. Students have skills in composing good sentences when communicating with others. The way students with hearing impairment communicate will get better in line with the level of education they are taking. At every level of education that he goes through, he will provide experience and new additions related to vocabulary and sentence arrangement (Hermanto, 2011). Mathematics almost all students have low scores compared to science, vocational programs, and Indonesian. Mathematics is a subject that is difficult for students with hearing impairments because they contain many abstract concepts. In addition, the 
stigma of mathematics is a difficult subject, it also happens in special schools. That is also the reason why mathematics learning in special schools is not optimal (Syafrudin and Suwarjo, 2019).

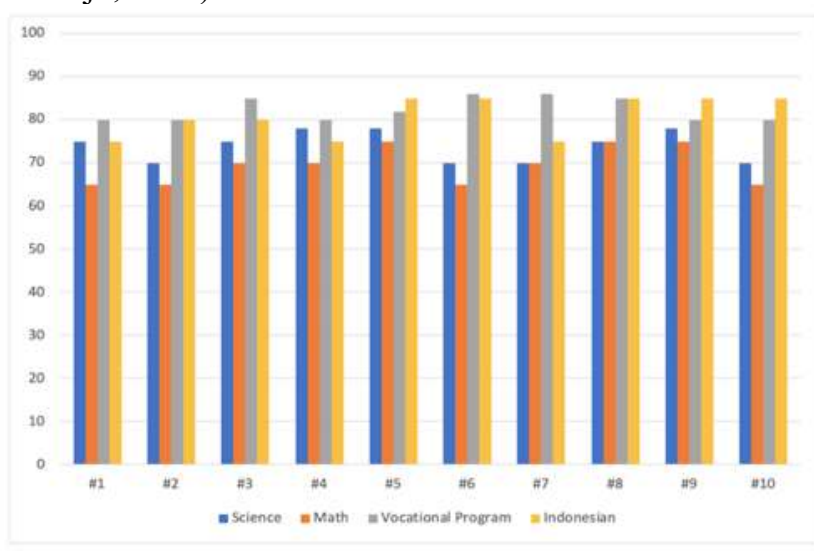

Fig. 3 Data on student's academic result

Note: \#1- \#10: students

Table 1 describes the characteristics of the participants in this study. Knowing the characteristics of each individual before providing the right strategy in teaching tempe making is also important. The process of getting information for students with hearing impairments requires a long process. Starting with the entry of information through sensory, followed by the storage process knowledge, generate knowledge, then the response. Knowing how students with hearing impairments communicate will help teachers in providing the right stimulus (Hermanto, 2012). The type of communication used by 10 students with hearing impairments in this study is total communication, which combines the use of sign language, oral, spoken reading, and writing in communicating. Total communication is one type of communication that is effective for Student with Hearing Impairments, because it uses various ways that combined in communication, such as in Mudjiyanto's research with the title of students with hearing impairments communication in state special school section B of Jayapura (Mudjiyanto, 2018).

Residual hearing or the hearing ability of 10 deaf students was also found to be at moderate classification. Classification of hearing impairment based on hearing ability is light hearing loss $(15-30 \mathrm{~dB})$ comprehension of normal human speech, moderate hearing (31-60 dB) hearing ability of human voice is only partially, with severe hearing loss (61-90 dB) Human speech voice is absent, deaf is very heavy (91-120 dB) and is totally deaf or deaf (more than 120 $\mathrm{dB}$ ) the comprehension of the human voice is absent at all [29]. So, students with hearing impairments who became participants still had their hearing remaining so they could still hear some human voices. The use of hearing aids affects the way deaf students who use them communicate. For those who have successfully adapted to the use of hearing aids, this type of oral communication can be done (Somad, 2008).

Collection of the abilities and needs of students before the learning process is the principle of developing services or programs for children with special needs. The stages of developing an education program for special needs students are first, identify the student with special needs; second, special needs assessment, third education program plan; fourth, implementation program; and fifth, the evaluate education program. All of these stages must be communicated and coordinated (Lewis, Rena, Doorlag and Donald, 1986).

\begin{tabular}{|c|c|c|c|c|c|}
\hline Student & $\begin{array}{c}\text { Age } \\
\text { (Years) }\end{array}$ & Gender & $\begin{array}{c}\text { Hearing } \\
\text { Ability (dB) }\end{array}$ & $\begin{array}{c}\text { How to } \\
\text { Communicate } \\
\end{array}$ & Other Information \\
\hline$\# 1$ & 21 & Female & 56 & $\begin{array}{c}\text { total } \\
\text { communication }\end{array}$ & sometimes use own sign language \\
\hline$\# 2$ & 20 & Female & 57 & $\begin{array}{c}\text { total } \\
\text { communication } \\
\end{array}$ & use hearing aid, sometimes use own sign language \\
\hline$\# 3$ & 20 & Female & 57 & $\begin{array}{c}\text { total } \\
\text { communication }\end{array}$ & sometimes use own sign language \\
\hline \#4 & 21 & Female & 55 & $\begin{array}{c}\text { total } \\
\text { communication }\end{array}$ & use hearing aid, sometimes use own sign language \\
\hline$\# 5$ & 19 & Female & 57 & $\begin{array}{c}\text { total } \\
\text { communication }\end{array}$ & sometimes use own sign language \\
\hline \#6 & 20 & Male & 57 & $\begin{array}{c}\text { total } \\
\text { communication }\end{array}$ & sometimes use own sign language \\
\hline \#7 & 21 & Female & 56 & $\begin{array}{c}\text { total } \\
\text { communication }\end{array}$ & sometimes use own sign language \\
\hline \#8 & 20 & Female & 54 & $\begin{array}{c}\text { total } \\
\text { communication }\end{array}$ & use hearing aid, sometimes use own sign language \\
\hline$\# 9$ & 20 & Female & 56 & $\begin{array}{c}\text { total } \\
\text { communication }\end{array}$ & sometimes use own sign language \\
\hline$\# 10$ & 20 & Male & 56 & $\begin{array}{c}\text { total } \\
\text { communication } \\
\end{array}$ & sometimes use own sign language \\
\hline
\end{tabular}




\subsection{Experiment results}

Figure 3 shows the experimental results of making tempe from various particle sizes of soybeans. First: the particle size of the soybeans used is approximately 50-1100 um, which is called fine powder. After blended soybeans are dried, the result is almost like flour but still lumpy because the conditions are still moist. Tested with 3 variants of the amount of yeast used. The weight of mashed soybeans is 900 grams, each plastic contains 300 grams of soybeans, and each plastic uses a different yeast, namely 1, 2, and 3 tsp. The third bag using 3 tsp yeast had a thicker fungus than the 1st and 2nd bags which used less yeast (see Figures 3a.1-3. a3). Second: the particle size of the beans used is approximately 100-1000 um, which is called coarse powder. Third: the particle size of the beans used is approximately 1000- $3360 \mathrm{um}$. The treatment is the same as the type of fine powder particle size.

Too low levels of starter $\left(10^{2} \mathrm{CFU} \mathrm{g-{ } ^ { 1 }}\right.$ or less $)$ give irregular fungal growth, longer fermentation periods, and higher chances of bacterial spoilage. But too high levels $(\geq$ $10^{6} \mathrm{CFU} \mathrm{\textrm {g } ^ { - 1 }}$ ) of the starter may result in 'stormy' fermentation with an excessive increase of temperature in the tempe and premature death of the mold (Nout and Kiers, 2005). It is necessary to pay attention to the amount of yeast used when making tempe so that the quality of the tempe is
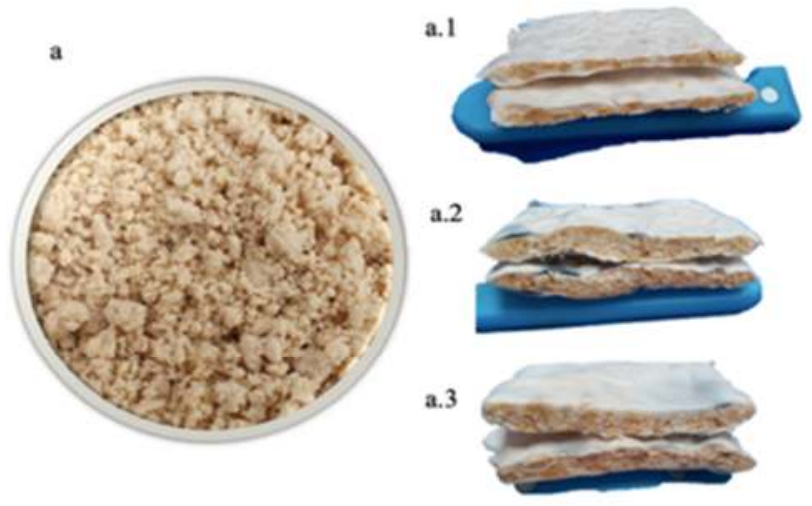

c

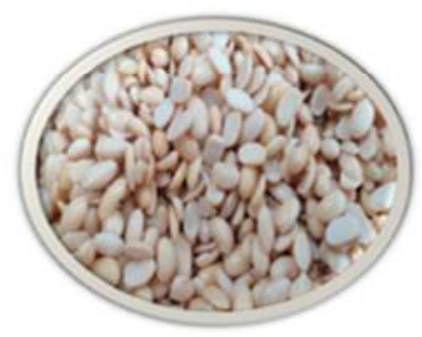

good. If used too much yeast on soybeans, generally, the result is rotten tempe.

Table 2 describes the quality of tempe made from various particle sizes of soybeans. The method of calculating durability is that the tempe is weighed, drop it from a height of 2 meters, then the lump is weighed, and find the difference between the chunk and the weight of the whole tempe. Particle size with 3 tsp of yeast has good durability compared to 1 and 2 tsp of soybean particles. Excellent Durability cornsoybean using yeast 3 tsp than 1 and 2 tsp, in line with the research (Aini, Hariyadi, Muchtadi, and Andarwulan, 2010). The fungus that is produced by a lot of yeast, evenly distributed, and fermented at a suitable temperature will bind the soybean particles perfectly (Mukhoyaroh, 2015). There are differences in the durability of the three forms of tempe. Tempe made from mashed soybeans, even though it has used a lot of yeast, is still easily crushed than chopped tempe. The best durability is tempe, made with whole soybeans, and uses three teaspoons for every 300 grams.

The aroma of tempe produced by various particle sizes of soybeans was no difference. One of the characteristics of good quality tempe is the smell of fresh mold. The good color of tempe is pure white which is produced by yeast and grows into mold, resulting in the aroma of fresh mold plants (Kustyawati, 2017).
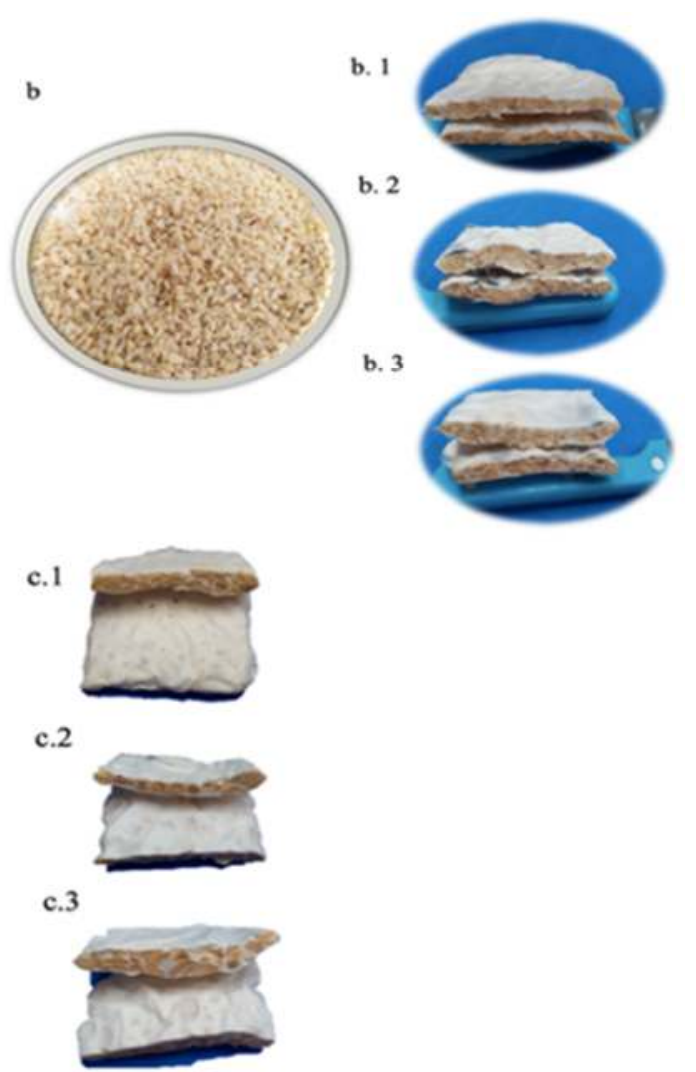
Fig. 3 The experimental results of making tempe from various particle sizes of soybeans: (a) soybean fine powder; (b) crude soybean powder; (c) whole soybeans (a.1, a.2, a.3) fine powder using 1-3 tsp yeast; (b.1, b.2, b.3) a coarse powder using 1-3 tsp yeast; (c.1, c.2, c.3) Whole soybeans use 1-3 teaspoons of yeast.

Table 2 Quality of tempe from various soybean particle sizes

\begin{tabular}{|c|c|c|c|c|}
\hline \multirow{2}{*}{$\begin{array}{l}\text { Types of } \\
\text { Soybean } \\
\text { Particles }\end{array}$} & \multirow{2}{*}{$\begin{array}{l}\text { Yeast } \\
\text { used } \\
\text { (tsp) }\end{array}$} & \multicolumn{3}{|c|}{ Quality of the tempe } \\
\hline & & Durability (g) & Aroma & Color \\
\hline \multirow{3}{*}{$\begin{array}{l}\text { Fine } \\
\text { powder }\end{array}$} & 1 & 125 & Fresh fungi smell & White, not all soybeans are covered with fungus \\
\hline & 2 & 175 & Fresh fungi smell & White, thick fungus \\
\hline & 3 & 225 & Fresh fungi smell (strong) & White, thick fungus \\
\hline \multirow{3}{*}{$\begin{array}{l}\text { Coarse } \\
\text { powder }\end{array}$} & 1 & 200 & Fresh fungi smell & White, black in the plastic hole \\
\hline & 2 & 215 & Fresh fungi smell & White, black in the plastic hole, thick mushroom \\
\hline & 3 & 255 & Fresh fungi smell (strong) & White, black in the plastic hole \\
\hline \multirow{3}{*}{$\begin{array}{l}\text { Whole } \\
\text { soybeans }\end{array}$} & 1 & 175 & Fresh fungi smell & White, not all soybeans covered in mildew \\
\hline & 2 & 215 & Fresh fungi smell & White, thick mushrooms \\
\hline & 3 & 250 & Fresh fungi smell (strong) & White, thick mushrooms \\
\hline
\end{tabular}

\subsection{Teaching results}

Table 3 shows the results of the pretest and posttest of students with hearing impairments about the knowledge of biotechnology in making tempe. Student \#6 has experienced a significant improvement in understanding biotechnology materials in making tempe. All students with hearing impairments have improved in understanding this material. Student \#7 has not met the minimum completeness criteria in the high school science curriculum (70). Student \#7 tends to use its own sign language when communicating with other people, and cannot speak Indonesian sign language. This is one of the obstacles when teaching students with hearing impairments, the difference in sign language used also becomes a barrier to communication. This was an obstacle when providing videos facilitated by the Indonesian Sign System interpreter. Several times if student \#7 did not understand the translator he would ask his friends to repeat it.

Table 3. The level of student knowledge about producing tempe (biotechnology) from pretest and posttest result

\begin{tabular}{|c|c|c|}
\hline \multirow{2}{*}{ Student } & \multicolumn{2}{|c|}{ Score } \\
\cline { 2 - 3 } & Pre-test & Post-test \\
\hline$\# 1$ & 41.66 & 75.00 \\
\hline$\# 2$ & 25.00 & 83.33 \\
\hline$\# 3$ & 50.00 & 66.66 \\
\hline$\# 4$ & 41.66 & 75.00 \\
\hline$\# 5$ & 33.33 & 75.00 \\
\hline$\# 6$ & 58.33 & 91.66 \\
\hline$\# 7$ & 25.00 & 66.66 \\
\hline$\# 8$ & 41.66 & 75.00 \\
\hline$\# 9$ & 50.00 & 75.00 \\
\hline$\# 10$ & 33.33 & 83.33 \\
\hline
\end{tabular}

Table 4 describes the analysis of students' answers about the concept of making tempe (biotechnology). On the question "What is the definition of conventional biotechnology?" students' scores decreased. This problem is based on the abstract concept of biotechnology to explain it. These individuals have hearing problems that are so severe that speech cannot be understood when it is transmitted through the ear (Chen, Li, Li, Ahmad, Kamal and Huo, 2020). Whereas hard-of-hearing individuals can still use the auditory channel as their major avenue for speech and language development, deaf individuals must rely on the visual channel (Taylor and Sternberg, 1989). Teaching deaf, teachers must understand how their characteristics and how the principles of learning. Hearing impairment student knowledge, based on the student learning environment. Comprehension for the beginning is assisted from the reading process, which is genuinely deaf students (Alasim, 2020)

Table 4. Analysis of the students' answer to the concept making tempe

\begin{tabular}{|c|c|c|c|c|}
\hline \multirow[t]{2}{*}{ No } & \multirow{2}{*}{ Questions } & \multicolumn{2}{|c|}{ Skor (\%) } & \multirow{2}{*}{ Gain } \\
\hline & & Pre & Post & \\
\hline 1 & $\begin{array}{l}\text { What is the definition of } \\
\text { biotechnology? }\end{array}$ & 66.66 & 83.33 & 16.67 \\
\hline 2 & $\begin{array}{l}\text { What is the definition of } \\
\text { conventional biotechnology? }\end{array}$ & 83.33 & 81.50 & -1.83 \\
\hline 3 & $\begin{array}{l}\text { What is the definition of } \\
\text { modern biotechnology? }\end{array}$ & 50 & 72.20 & 22.2 \\
\hline 4 & $\begin{array}{l}\text { Mention examples of } \\
\text { conventional biotechnology! }\end{array}$ & 50 & 87.50 & 37.5 \\
\hline 5 & $\begin{array}{l}\text { Mention examples of modern } \\
\text { biotechnology! }\end{array}$ & 66.66 & 100 & 33.34 \\
\hline 6 & $\begin{array}{l}\text { What is the name of the fungus } \\
\text { used in making tempe? }\end{array}$ & 33.33 & 100 & 66.67 \\
\hline 7 & $\begin{array}{l}\text { What is the definition of } \\
\text { fermentation in food } \\
\text { processing? }\end{array}$ & 33.33 & 72.20 & 38.87 \\
\hline 8 & $\begin{array}{l}\text { Sort out the correct process of } \\
\text { making tempe! }\end{array}$ & 38.90 & 72.20 & 33.3 \\
\hline 9 & $\begin{array}{l}\text { What are the characteristics of } \\
\text { high quality of tempe? }\end{array}$ & 66.66 & 83.33 & 16.67 \\
\hline 10 & $\begin{array}{l}\text { How long does it take for } \\
\text { tempe to ferment? (minimum) }\end{array}$ & 83.33 & 100 & 16.67 \\
\hline 11 & $\begin{array}{l}\text { What are the benefits of } \\
\text { biotechnology to humans? }\end{array}$ & 33.33 & 100 & 66.67 \\
\hline 12 & $\begin{array}{l}\text { What are the characteristics of } \\
\text { inedible tempe? }\end{array}$ & 50 & 100 & 50 \\
\hline
\end{tabular}


The lowest scores of students with hearing impairments in answering the pretest questions: "What is the name of the fungus used in making tempe?", "What is the definition of fermentation in food processing?", "What are the benefits of biotechnology to humans?" occurred. Explaining structured procedures and using complete sentences is also difficult for students with hearing impairments. Describing something using clear and complete sentences is very difficult for deaf students to do (Sobreira, Capo, Dos Santos and Gil, 2015). However, the difficulty was solved with the appropriate strategies. The experiment demonstration helps students with hearing impairments to be independent in developing thinking and language skills with the teacher as facilitator. Based on the aforementioned, it can be seen with improved posttest results. As for question number six, it increased to $66.67 \%$, question number seven increased by $38.87 \%$, and question number eleven increased by $66.67 \%$.

Current science teaching presents a range of difficulties for students with hearing impairments particularly when abstract concepts are delivered using a didactic approach with a reliance on text-books (Jones, 2014). In delivering material to students with hearing impairments, the teacher must pay attention to the sign language used. In addition, writing is also a form of communication for deaf students. The written method is useful when the written method allows deaf people and listeners to communicate by using wellknown characters. However, the drawback is that the written method has a slow communication speed and many constraints to the use environments (Meristo and Strid, 2020). Therefore, finding out whether students understand the sign language system being is used is also important. Experiments help students with hearing impairments to understand the differences in density in the fluid because the activities are structured and include elements of fun activities. This method helps students develop their language skills by re-demonstrating the experimental activities they have conducted.

\section{Conclusions}

The demonstration experiment strategy of the biotechnology material for making tempe from various particle sizes of soybeans has been taught to ten students with hearing impairments in high school. This strategy helps the students with hearing impairments in having a pleasant learning experience, increasing their motivation, and making the topic easy to understand because the strategy prioritizes hearing impairments learning principles. Additionally, paying attention to the characteristics, abilities, and learning needs of students with hearing impairments influences the effectiveness of teaching. This study showed that students with hearing impairments are able to learn the biotechnology of making tempe from various particle sizes of soybeans. The theory in biotechnology includes abstract vocabulary and sentences, however, students can get good grades. This means that science learning for students with hearing impairments in the future can be implemented and developed. The hearing abilities do not hinder learning various sciences. Through extensive and developing material, students with hearing impairments' vocabulary will increase.

\section{Acknowledgements}

We would like to thank Universitas Pendidikan Indonesia for supporting and encouraging this study.

\section{References}

Aini, N., Hariyadi, P., Muchtadi, T. R., and Andarwulan, N. (2010). Hubungan antara waktu fermentasi grits jagung dengan sifat gelatinisasi tepung jagung putih yang dipengaruhi ukuran partikel [relationship between fermentation time of corn grits and gelatinization properties of white corn flour influenced by particle. Jurnal Teknologi Dan Industri Pangan, 21(1), 18-18.

Alasim, K. (2020). Understanding factors that affect the prior knowledge of deaf and hard of hearing students and their relation to reading comprehension. Deafness and Education International, 22(3), 232-250.

Chang, C. T., Hsu, C. K., Chou, S. T., Chen, Y. C., Huang, F. S., and Chung, Y. C. (2009). Effect of fermentation time on the antioxidant activities of tempe prepared from fermented soybean using Rhizopus oligosporus. International Journal of Food Science and Technology, 44(4), 799-806.

Chen, P., Li, Z., Li, Y., Ahmad, S. S., Kamal, M. A., and Huo, X. (2020). The language development via foxp2 in autism spectrum disorder: A review. Current Pharmaceutical Design. 26 (37), 4789 - 4795

de Oliveira Sobreira, A. C., Capo, B. M., Gil, D., and Dos Santos, T. S. (2015). Speech and language development in hearing impairment: Two-case report. Revista CEFAC, 17(1), 308-317

Farooq, G. (2011). Evaluation of curriculum of vocational subjects for hearing impaired children. Interdiciplinary Journal of Contemporary Research in Business. 3 (5). 352-359

Hassanein, T. R., Prabawati, E., and Gunawan-Puteri, M. D. P. (2015). Analysis of chemical and microbial change during storage of overripe tempe powder as seasoning material. Journal of Science and Engineering, 8(2), 131-134.

Hermanto .(2011). Penguasaan kosakata anak tunarungu dalam pembelajaran membaca melalui penerapan metode maternal. Majalah Ilmiah Pembelajaran, 2(15), 120-135

Hermanto. (2012). Strategi pembelajaran kosa kata abstrak untuk meningktakan kemampuan berbahasa anak tunarungu usia dini. Majalah Ilmiah Pembelajaran $1(1), 39-50$

Hidayat, N. (2009). Tahapan Proses Pembuatan Tempe. Universitas Brawijaya. Malang.[Indonesia].

Jones, Lindsey. (2014). Developing Deaf Children's Conceptual Understanding and Scientific Argumentation Skills: A Literature Review. 
Deafness and Education International, 16(3), 146160

Kharisma, H., Mahadi, I. and Darmawati (2015). Pengembangan LKS SMA pada materi bioteknologi konvensional melalui eksperimen pembuatan tempe menggunakan berbagai jenis kacang. Jurnal Online Mahasiswa Fakultas Keguruan dan Ilmu Pendidikan Universitas Riau, 2(2), 1-10.

Kustyawati, M. E. (2017). Profile of aroma compounds and acceptability of modified tempe. International Food Research Journal 24 (2), 734-740.

Lewis, Rena B, Doorlag, and Donald H.(1986). Assessing Special Student, Second Edition. USA: Merril Publishing Company.

Liu, Keshun.(2015). Soybeans (Chemistry, Production, Processing and Utilization). USA: Academic Press and AOCS Press.

Mariani, R., Delou, C. M., Souza, A., Valentim, V. R., Passos, D. D., Rosa, A., Farias, L., Marrocos Moraes, K. F., and Castro, H. C. (2014). Biotechnology: A non-existing word/world for the Brazilian deaf community. BMC Proceedings, 8(Suppl 4), P262.

Marschark, M., and Wauters, L. (2008). Language comprehension and learning by deaf students. In $\mathrm{M}$. Marschark and P. C. Hauser (Eds.), Perspectives on deafness. Deaf cognition: Foundations and outcomes. (309-350).

Meristo, M., and Strid, K. (2020). Language first: Deaf children from deaf families spontaneously anticipate false beliefs. Journal of Cognition and Development, 21(4), 1-9.

Mudjiyanto, B. (2018). Pola komunikasi siswa tunarungu di sekolah luar biasa negeri bagian B kota Jayapura. Jurnal Studi Komunikasi Dan Media, 22(2), 151-166.

Mukhoyaroh, H. (2015). Pengaruh jenis kedelai, waktu dan suhu pemeraman terhadap kandungan protein tempe kedelai. Florea: Jurnal Biologi dan Pembelajarannya, 2(2), 47-51.

Mulyono, Y., Bintari, S. H., Rahayu, E. S., and Widiyaningrum, P. (2012). Pengembangan perangkat pembelajaran dengan pendekatan scientific skill teknologi fermentasi berbasis masalah lingkungan. Lembaran Ilmu Kependidikan,41(1), 20-26.

Murata, K., Ikehata, H., and Miyamoto, T. (1967). Studies on the nutritional value of tempe. Journal of Food Science, 32(5), 580-586.

Nandiyanto, A. B. D., Raziqi, G. Y., Dallyono, R., and Sumardi, K. (2020). Experimental demonstration for enhancing vocational students' comprehension on heat transfer through conduction and radiation of light bulb. Journal of Technical Education and Training, 12(3), 189-195.

Nehru, N. and Syarkowi A.(2017). Analisis desain pembelajaran untuk meningkatkan literasi sains berdasarkan profil penalaran ilmiah. Wapfi (Wahana Pendidikan Fisiki), 2(1), 20-24
Nout, M. J., and Kiers, J. L. (2005). Tempe fermentation, innovation and functionality: Update into the third millenium. Journal of Applied Microbiology, 98, 789-805.

Ntinda, K., Thwala, S.K. and Tfusi, B (2019) Experience of teachers of deaf and hard-of-hearing students in a special needs school: An exploratory study. Journal of Education and Training Studies, 7(7), 79-89

Ohlenforst, B., Zekveld, A. A., Jansma, E. P., Wang, Y., Naylor, G., Lorens, A., Lunner, T., and Kramer, S. E. (2017). Effects of Hearing Impairment and Hearing Aid Amplification on Listening Effort: A Systematic Review. Ear and hearing, 38(3), 267-281.

Polanowska, K., Grygier, A., Kuligowski, M., Rudzińska, M., and Nowak, J. (2020). Effect of tempe fermentation by three different strains of Rhizopus oligosporus on nutritional characteristics of faba beans. $L W T, 122,109024$.

Rahayu, S. (2020). Efek Kombinasi Yakult Dan Tapioka Pada Proses Pembuatan Tempe Terhadap Ketahanan Tempe Dan Implementasinya Dalam Pembelajaran Biologi Berbasis Sets Di Kelas X Sma Tunas Patria Ungaran Kabupaten Semarang. INKUIRI: Jurnal Pendidikan IPA, 9(1), 68-74.

Setiawati, Lilis, Darmawati, and Imam Mahadi.(2016). Pengembangan Lks SMA pada Materi Bioteknologi Konvensional melalui Eksperimen Pembuatan Tempe Menggunakan Bahan Baku Biji Karet. Jurnal Online Mahasiswa Fakultas Keguruan dan Ilmu Pendidikan Universitas Riau, 3 (2), 1-11.

Somad, P. (2008). Definisi dan Klasifikasi Tunarungu. Online. Tersedia dalam: http://permanarianl6. blogspot. com/.../definisi-danklasifikasi-tunarungu. html.[8 November 2012].

Sulfanita, S., and Zulmiyetri, Z. (2018). Pengaruh Model Explicit Instruction dalam Meningkatkan Keterampilan Vokasional Membuat Tempe bagi Anak Tunarungu. Jurnal Penelitian Pendidikan Khusus, 6(2), 303-307.

Supriyanto, S. (2020).Pengelolaan Layanan Keterampilan Vokasional Siswa Tunarungu. Jurnal Inspirasi Manajemen Pendidikan 8(3), 167-177

Syafrudin, T., and Sujarwo, S. (2019). Pengembangan Bahan Ajar Untuk Pembelajaran Matematika Bagi Siswa Tunarungu. Suska Journal of Mathematics Education, 5(2), 87-94.

Tanjung, L.(2019) Vlog Experiental Learning Pada Materi Teknik Fermentasi Tempe Produk BioteknologI. Pedagogia, 17(3), 273-279.

Taylor R.L., Sternberg L. (1989) Students with Hearing Impairments. In: Exceptional Children. Springer, New York, NY.

Utami, R., Wijaya, C. H., and Lioe, H. N. (2016). Taste of water-soluble extracts obtained from over-fermented tempe. International Journal of Food Properties, 19(9), 2063-2073. 